\title{
THE Question OF CHANGING THE CONCEPT, ROLE AND FUNCTIONS OF STATE
}

\author{
JOSÉ G. VARGAS-HERNÁNDEZ
}

\begin{abstract}
This paper on the question of the concept, role and functions of State, attempts to critically analyze recent developments and transformations. It is assumed that all existing State models to date are in ideological crisis that challenges the concept of State. The problem is that the empirical evidence of the role and functions of the State or the State system are different from a standpoint of a range of spheres of government, which generate the multiple requirements of the regulatory activity of the State. In the discussion some questions are identified and proposals that may be useful for analyzing the transformation of the State are formulated.
\end{abstract}

KEYWORDS: Concept of State; State Functions; Role of Government.

\footnotetext{
${ }^{\dagger}$ Professor, Center for Economic and Managerial Sciences, University of Guadalajara, México.
} 
RESUMEN: Este trabajo sobre la cuestión del concepto, papel y funciones del Estado intenta analizar en forma crítica los desarrollos y transformaciones recientes. Se parte del supuesto de que todos los modelos de Estado hasta hora existentes están en crisis ideológica que cuestiona el concepto de Estado. El problema es que la evidencia empírica del papel y funciones del Estado o el sistema del Estado es diferente desde un punto de vista de un rango de esferas de gobierno, en el cual se generan los múltiples requerimientos de la actividad regulatoria del Estado. En la discusión se delimitan algunos cuestionamientos y se formulan propuestas que pueden ser de utilidad para el análisis de la trasformación del Estado.

Palavras-Chave: Concepto de Estado; Funciones del Estado; Papel del Estado. 


\section{TABLE OF CONTENTS:}

I. INTRODUCTION: THE CONCEPT OF STATE ..........................................271

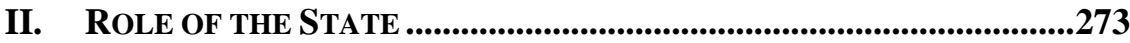

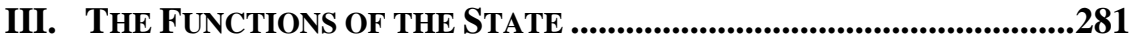

IV. DISCUSSION: THE QUESTION ..............................................................288

V. REFERENCES ..........................................................................................291

\section{SUMÁRIO:}

I. INTRODUÇÃO: O CONCEITO DE ESTADO.............................................271

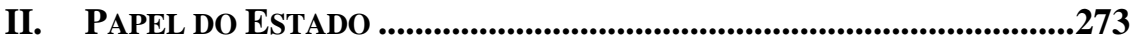

III. AS FUNÇÕES DO ESTADO .......................................................................281

IV. DISCUSSÃO: A QUESTÃO ...........................................................................288

V. REFERÊNCIAS ...........................................................................................291 


\section{INTRODUCTION: THE CONCEPT OF STATE}

Recent changes in political practices have made it necessary to redefine the concept of the State. In Smith's invisible hand of the market, the State content only ensure the market is able to exercise its function without hindering their work and protect it from outside interference. ${ }^{1}$ The "State idea" conceived by Adams considers the State as an actor, a coherent entity with preferences and ability to pursue them.

The State is the main element of competition for power and the legitimate monopoly of violence, base of its own security. For Weber, the State is a set of structures and institutions in authority, a legitimate monopoly of coercion on a given territory, where markets (economic) and the State (political) are different areas but separated. In the Weberian concept, the State monopolizes power and the legitimate use of coercion. The State concentrates the exercise of political power in autonomous and sovereign manner over a people and a territory through a set of institutions, a body of officials and procedures regulated, according to Fleury. ${ }^{2}$

Since neo Marxist theories, discussions are made about the influence of the class struggle in the welfare State. ${ }^{3}$ The State is relatively autonomous in mediation processes between social classes that operate at different levels. However Skocpol emphasizes the role of government in the development of the welfare State in contrast to the neo-Marxist theory by arguing that it is not simply a reflection of the interest demands of social classes and social groups. ${ }^{4}$

The legal form of the State is based on the concept of nationalism with a reality regulated in a Constitution that stands between the people or polity and humanity, and therefore becomes the nation being historical while the people is society current at a given time. The nation arouses the feeling of emotional loyalty that facilitates the processes of governance of the people who cannot achieve higher institutions as humanity, the continent or linguistic community. Nationalism is based on the primacy

\footnotetext{
${ }^{1}$ See Estefanía, J. "La enfermedad moral del capitalismo", Granito de arena, Agosto 7 del 2002, Argentina (2002).

2 Fleury, S. Reforma del Estado en América Latina. Hacia dónde?, 160 NuEVA SOCIEDAD 58 (1999).

${ }^{3}$ In the neo-Marxist approach, see QuADAGNO, J.B., THE TRANSFORMATION OF OlD AGE SECURITY: ClASS AND POLITICS IN THE AMERICAN WELFARE STATE (1988).

${ }^{4}$ Skocpol, T., Bringing the State Back in: Strategies of Analysis in Current Research, in BRINGING THE STATE BACK IN (Evans, P.B., Rueschemeyer, D. \& Skocpol, T. eds., 1985).
} 
of politics over the economy on the basis that State intervention is in defense of national interests, assuming a zero sum game.

Nationalism is the characteristic political and cultural trait of the twentieth century and has served to justify the liberation of peoples and the assertion of regionalism. Nationalism emerged from antagonism toward others, unsocial unsociability of men according to Kant. Nationalism emerged as a defensive mechanism of peoples and as an expression of a political community that matures to form a nation-State but insecurity to consolidate maintaining internal social cohesion, despite factors that militate against it.

Political, civic, social and legal as elements of a draft social life rights are exercised in the context of the nation State, entity that forms the will of a people to establish peaceful relations elements, cultural bond and understanding with other cultures.

There is a sparked a movement for a new world order. The strong ideological campaigns assume that against market forces, the State is increasingly irrelevant. For some analysts, such as Peón Solís, the future of the State is virtually sealed to have become incapable instance to rid of the overwhelming thrust of economic dynamics and strength of global connections. ${ }^{5}$ Therefore, given the determination of the external order of the State, it has not only been undermined its autonomy and eroded its ability to carry out the role it deserves in the domestic realm.

It is noteworthy differences between the idea of the State and the State system in which the government at different levels, federal, State or municipal guarantees the deregulatory strategy seeking a more deregulated environment. However, there are difficulties. Deregulation is the means by which governments achieve their goals, but it is difficult for governments to change due to the fact that deregulation reflects the preferences of a number of interest groups and political leaders have acquiesced.

Once the regulatory framework is implemented, it becomes part of the routine of life and those who are accustomed not find a reason to change. The enthusiasm of governments and the OECD for greater competitiveness is not shared neither by regulators or existing businesses shielded behind the regulatory wall. All these questions lead to reformulate the concept of the State as a concept for understanding the processes of government.

${ }^{5}$ Peón Solís, A., A propósito de la globalización: ¿es inminente la desaparición del Estado?, 102 Este PAís: TENDENCIAS Y OPINIONES 33 (1999).

1 JOURNAL OF INSTITUTIONAL STUDIES 1 (2015) 


\section{ROLE OF THE STATE}

In an attempt to create a typology of approaches to economic organization, Dunning identifies six roles of government in a marketoriented economy: The political and economic interests of the State should be the main justification for the (mercantilist) economic activity, regulate the affairs according to a natural order (Physiocrats), the "invisible hand" of the market as the best allocator of resources (classical and neoclassical), an active and participatory role of the State in all aspects of economic affairs (socialist) economy, the welfare of the community and national dividend distribution (welfare economics), personal freedom and against State intervention (contractarianism) and lack of confidence in the efficiency and social justice in the economy market justifies State intervention (structuralism). ${ }^{6}$

From the perspective of structuralism, the roles of social classes and the State are related. It is argued that welfare State programs are not only elements in advancing capitalist countries since public benefits develop functions to provide support to social classes and vulnerable workers and assign jobs through employment programs.

Besides, functionalism was a response to the needs of society at a certain stage of industrial development on the basic assumption that economic and social change determines the functions of the State. ${ }^{7}$ This approach highlights the role of welfare spending in an industrial society and therefore the functions that adopts, sometimes considered as a result of processes involving conflicting tendencies toward economic, social and political crisis. This theory argues that markets are more satisfying the needs of consumers and users than services programs of the State, but is accused of providing intellectual and technological determinism resulting in commercialism of welfare services.

The State welfare systems are defined by the different levels of development and ways to interconnect with each other institutional, organizational and welfare elements and mechanisms involved. Differ not only in terms of the proportion of national wealth but in the way of its internal elements and how they are organized and operate and welfare

\footnotetext{
${ }^{6}$ Dunning, J. H. Governments and the macro-organization of economic activity: an Historical and spatial perspective, 4 REVIEW OF INTERNATIONAL POLITICAL ECONOMY 1 (1997). 7 See Wilensky, H., The Welfare State and Equality (1975); Wilensky, H., THE WELFARE STATE AND EQUALITY: STRUCTURAL AND IDEOLOGICAL ROOTS OF PUbliC EXPENDITURES (1975).
} 
mix. Such that for each case it has come to question the type of welfare system that is. For example, some States privilege more national security but ignore the important role of social services. ${ }^{8}$

The conservative regimes that have political support are guided by a focused restructuring strategy welfare programs and cost containment that meet social demands. ${ }^{9}$ Pierson and Smith noted that conservatives in public practice favor reduction in size and scope of the welfare State's functions. ${ }^{10}$ However, even in the case of conservative parties cutbacks in social policy are generally unpopular. ${ }^{11}$ Conservative governments seek revisualization of the welfare State. What was happening was a change of profound importance, a narrowing of the role and functions of the welfare State from the provision of welfare for all the very different role of providing only for the needs of the poor.

In the context of globalization, global capitalist imperialism reformulates the idea of State and System State and thus the entire welfare system. $\mathrm{O}^{\prime}$ Connor argues that the State in capitalist society meets basic and contradictory functions of accumulation and legitimation. ${ }^{12}$ The State's role in economic development has changed dramatically since the crisis of the eighties and accelerated the processes of globalization, radically rejecting the responsibilities of the welfare State and deepening the negative effects of social differentiation and dissociation of social life in broad sectors of communities.

Welfare State model is subjected to a critical attack by some analysts that show its shortcomings and dysfunctions in the allocation of resources, who also highlights the advantages to transfer this responsibility to the market. State management is attacked with arguments that weaken the private management of individuals and

\footnotetext{
8 See Alber, J. A framework for the comparative study of social services, 5 JOURNAL OF EUROPEAN SOCIAL POliCY 2 (1995); Alber, J. Continuity and change, 16 POLITICS AND SOCIETY 4 (1995).

9 See Pierson, P., Post-Industrial Pressure on the Mature Welfare States, in THE NEW Politics Of The Welfare State (Pierson, P. 2001); Pierson, P. Coping with Permanent Austerity: Welfare State Restructuring in Affluent Democracies, in THE NEW POLITICs OF the Welfare State (Pierson, P. 2001).

${ }_{10}$ Pierson, P. \& Smith, M. Bourgeois revolutions? The policy consequences of resurgent conservatism, 25 COMPARATIVE POLITICAL STUDIES 4 (1993).

${ }^{11}$ See Pierson, P. \& Smith, M. Bourgeois revolutions? The policy consequences of resurgent conservatism, 25 COMPARATIVE POLITICAL STUDIES 4 (1993).

${ }^{12}$ O'CONNOR, J. O., THE FisCAL CRISIS OF THE STATE (1973), pp. 6.
}

1 JOURNAL OF INSTITUTIONAL STUDIES 1 (2015) 
businesses as well as social resources. The crisis of the welfare State highlighted the need to reinvent the State, citizenship and government.

The crisis of the welfare State is a result of the economic crisis, i.e. essentially a fiscal crisis. To understand the important functions of the welfare State in its relations with foreign aid, these functions have to go beyond the indicators established by government spending and political parties. There are many cases which cannot be explained by the hypothesis of spending on the relationship between the welfare State and foreign aid. ${ }^{13}$

The sustainability of the generosity of the welfare State requires an economy with strong economic growth and a high level of productivity with strict administrative and legal controls on capital ownership and wellness resources that give space to the emergence of exogenous and endogenous forces. This control of the State is questioned because they weaken the prerequisites of the welfare State by pushing labor to form multiple networks of security forces.

The welfare State is not just a scene of social institutions and public budgets but first and foremost the result of certain power relations in society. In the model of the welfare State while the State is a crucial agent in the provision of social services, is not fully inserted into the power of relationships between the institutions of the State administration and users - beneficiaries, so not necessarily maintains a monopoly. The debate extends to the complementarity of the welfare State with the market in contrast to previous approaches such as social democrat who assumes that the welfare State is the result of the policy against market according to Esping-Andersen. ${ }^{14}$

The exhaustion of the development of Keynesian orientation resulted in a deep fiscal crisis of the State. The reforms implemented by the State to overcome this fiscal crisis were aimed at achieving macroeconomic stability measures that only increased the levels of poverty and social marginalization. Poverty is seen as the deprivation of basic capabilities understood as goals in themselves whether or not lead to greater revenue generation rather than understanding poverty as perceived low income.

${ }^{13}$ See Blais, A., Blake, D. and Dion, S. Do Parties Make a Difference? Parties and the Size of Government in Liberal Democracies, 37 American Journal OF POlitical SCIENCE 40

(1993); LuMSDAine, D. H. MORAL Vision In INTERnATIONAL POlitics: THE ForeigN Aid REGIME 1949-1989 (1993); Hicks, A. \& Misra, J., Political Resources and the Growth of Welfare in Affluent Capitalist Democracies, 1960-1982, 99 AMERICAN JOURNAL OF SOCIOLOGY 3 (1993).

14 Esping-Andersen, G. POlitics Against Markets: The SOCIAL DeMOCRATIC ROAD tO POWER (1985). 
The first generation of financial crisis in developing countries explains the crisis as a result of the inconsistencies between internal and external government policies. The combination of domestic policies combined with fixed exchange rate regimes led to the disappearance of foreign exchange reserves and then to the crisis. The crisis of the welfare State is the result of the growing social demand for care that cannot be covered financially by available resources and low levels of income.

Moreover, Myles \& Quadagno argue that at the very moment when the political theories of the welfare State are relegated to the logic of the theory of industrialism that emphasizes the roles of large impersonal economic forces, new spectra such as the new welfare policy are revived..$^{15}$ These political theories have relegated the thesis of the logic of industrialism emphasizing impersonal economic forces. ${ }^{16}$

The role of the democratic State conflicts with the globalization postindustrial capitalism between the processes of commodification and de-commodification of social policy. The processes of industrialization explain many of the changes in the functions of the welfare State. ${ }^{17}$ These were not explained at all, because situations analysis, interpretations and misconceptions about possible uniformity of changes in employment structures across countries. ${ }^{18}$

Massive changes in occupational structures that occur both in the manufacturing sector and in services in advanced economies pose a risk to weaken the productive structures and levels of growth. Hence, industrialization processes have an impact on occupational structures of the most advanced societies and are related to the changes in the functions of the welfare State. ${ }^{19}$ In fact, the changes in the powers and

${ }^{15}$ Myles, J. \& Quadagno, J., Political Theories of the Welfare State, 76 SOCIAL SERVICE REVIEW 1 (2002), pp. 41.

${ }_{16}$ Myles, J. \& Quadagno, J., Political Theories of the Welfare State, 76 SOCIAL SERVICE REVIEW 1 (2002), pp. 41.

${ }_{17}$ See Iversen, T. The Dynamics of Welfare State Expansion: Trade Openness, Deindustrialization, and Partisan Politics, in THE NeW Politics OF THE WeLfare STATE (Pierson, P. ed., 2001); Iversen, T. \& Cusack, T. R. The Causes of Welfare State Expansion: Deindustrialization or Globalization?, 52 WORLD POLITICS 3 (2000).

18 See Pontusson, J., Explaining the Decline of European Social Democracy: The Role of Structural Economic Change, 47 WORLD POLITICS 4 (1995).

${ }^{19}$ See Iversen, T. The Dynamics of Welfare State Expansion: Trade Openness, Deindustrialization, and Partisan Politics, in THE NeW POlitics OF THE Welfare STATE 
functions of the nation State has led to a reformulation of skills and social welfare functions at other levels of government, especially local and municipal is also presented.

This capability system of the welfare State allows local governments to decide on matters of the community to whom they have responsibility for their actions, although State reform amends its regulatory capacity and its role in protecting and assisting the community. In this context, social policies remain weak in the levels of local government and strongly dependent on domestic subsidies. Therefore, the different welfare State regimes promote different individual attitudes toward government functions through the creation of different enclaves of values. ${ }^{20}$

Therefore, if globalization is more related to the market with the State, then the State-market dualism is linked to the global-national dualism. The logic of a global economy is prevailing in the market while the logic of the State prevails in politics. The revolution in politics with the triumph of markets has been deeper leaning governments of the countries to embrace the global economy. In fact, the processes of economic globalization on the one hand, are dismantling the institutions and functions of the State, but on the other hand, are supporting their restructuring through new institutions and functions. However, reducing the role of government functions in economic policy is not a sufficient condition for the enablement of other institutions.

On one hand, the institutions of a social-democratic State are destroyed because it affirms the role of government to ensure effective protection of social rights. And on the other, the institutions of a liberal welfare State emerge because it believes in the market as an excellent, albeit imperfect, agent resource allocation, and sees outsourcing services and managed competition as excellent accountability tools. The radical liberalism emerged to support the functions of the welfare State for the provision of social programs. However, both the market liberalism and secular conservatism opposed to the welfare system have large dimensions.

Neoliberalism takes up the economic ideology of classical economic liberalism that although it had tried to delete the functions of the welfare State had only managed reforms. ${ }^{21}$ In the eighties the reforms called first

(Pierson, P. ed., 2001); Iversen, T. \& Cusack, T. R. The Causes of Welfare State Expansion: Deindustrialization or Globalization?, 52 WORLD POLITICs 3 (2000).

${ }^{20}$ See Svallfors, S., Worlds of Welfare and Attitudes to Redistribution: A Comparison of Eight Western Nations, 13 EUROPEAN SOCIOLOGICAL REVIEW 3 (1997).

${ }^{21}$ See O'Brien, M. \& PenNa, S., Theorising Welfare EnLightenMent AND Modern SOCIETY (1998). 
generation that redefine and reduce the State's functions under a new development model aiming at a growth oriented economic liberalization are presented. The economic growth strategy is oriented towards decentralization of State functions, participation and democratization. The strategy of neoliberal modernization has been absolute under an orthodox dogma that does not distinguish differences in development between national States. In this new world economic order development strategies are more focused on the modernization of the State through decentralization of functions.

Democratization processes represent a significant step to solve problems of economic, social, political development and strengthening governance through profound changes involving the definition of the boundaries between the public and private sectors, principles and processes State functions. However, the results of the implementation of these reforms are disappointing: the levels of inequality, social duality and increased social, economic and political instability rose.

The reforms of the second generation, also called constitutional reforms were aimed to make profound changes in institutions to adapt to the new profile model State, trying to understand all its functions according to certain patterns established in the Washington Consensus which implies changes in the rules such as the privatization of the provision of public goods and services.

The Washington Consensus promotes global economic liberalization of markets and liberal political democracy. The Washington Consensus defines the functions of the institutions of civil society and focuses its agendas and challenges to replace State functions, postulating a minimal government intervention in the market, economic liberalization and privatization of public enterprises. Thus, the Washington Consensus articulates a program of global political economy and restructuring of the political system based on democratic governance around free market as the only mainstream.

As a result of the foregoing, the State in general and specifically the Latin American States are in the process of institutional transformation under the premise that the market is best allocator of resources in the economy and that the functions of the State must achieve greater efficiency, transparency and probity in the use of resources aimed at promoting economic growth, equality of opportunity in meeting the social needs and demands, strengthen citizen participation and defense of its rights. However, a considerable degree of State power and the authoritarian government bureaucracy still remains in many Latin American countries. 
An analysis of international finance and corporate services can help show the differences between the role of the State in the previous forms of internationalization and today globalization of the obvious economic activities in certain economic sectors, according to Sassen..$^{22}$

But when the market begins to show its major flaws, the responsibility to correct them is transferred to the differential role of civil society. The marginal analysis of market failures identified two States: the first focused on externalities, imperfect competition and public goods that leave little room for State intervention and very little for the State provision of goods and services. ${ }^{23}$ The second focused on the internal effects among which are the effects on civil society. However, in reality many countries with advanced capitalist economies the role of the State exceeded the boundaries demarcated by the marginal theory.

Therefore, according to Torres-Rivas, the concept of civil society is associated with an ideological and conservative political version that aims to reduce the role of government and the public sector and strengthening private action that favors community associative life. ${ }^{24}$ In an information economy and society, collective action of social actors to renew and innovation processes of social organization allows widening and strengthening of democratic forms and the achievement of social development. Social movements arising from the crisis of legitimacy are motivated by a reconstruction of the State.

The national identity crisis is a result of the crisis of the nation State, i.e. the separation between the two, leading to the national ideology is replaced by the ideology of the market. The identity crisis of the nation State that is manifested in the loss of sovereignty and leads to the expression of a multicultural society is a product of the crisis of institutions that do not have the ability to resolve conflicts.

Moreover, the institutional crisis deepened by the lack of an ideology of identity, partly because the national identity dissociated from the State becomes ideology with responsibility in the development model. The institutional crisis deepens with the trend towards individualism charging political action in a fragmentation of social movements and

\footnotetext{
${ }^{22}$ Sassen, S., The State and the global city: Notes towards a conception of place-centered governance, 1 COMPETITION \& CHANGE 31 (1995).

${ }^{23}$ See Moudud, J. K. \& Zacharias, A., The social wage, welfare policy, and the phases of capital accumulation (The Jerome Levy Economics Institute Working Paper No. 291, 1999).

24 Torres-Rivas, E., La sociedad civil en la construcción democrática: notas desde una perspectiva crítica, 8/9 REVISTA INSTITUCIONES Y DESARROLLO 143 (2001), available at <www.iigov.org/iigov/pnud/bibliote/revista/revista8 9/docs/revis8 04.htm>.
} 
actors. The fragmentation weakens the security and stability that provide economic, political, social and cultural institutions. In this context, citizens tend to form coalitions of social welfare programs and remain in support. ${ }^{25}$ Coalitions of social classes explain past developments and future prospects of the different types of welfare State which is predominantly middle class, which is the most resistant to reduction of State functions.

In fact, the problem with global democracy is not a problem of lack of governance, as a result of the weakening of the role of the State by the processes of economic globalization, but because it is creating inequality between countries and between populations within each State because is an economic democracy.

The role of the neoliberal State rejects the obligations of the welfare State deepening the negative effects of social differentiation. The neoliberal State concentrates its efforts to alter the direction of government activities in a move to alter the centrality of its economic function that is parallel with activists' functions of the State in the processes of economic concentration and prioritization of social and economic relations.

The role of the State in regulating the economy has declined significantly as a result of the privatization processes of State assets, deregulation of economic activities, and the drastic reduction de los government spending and public employment. The measures to reduce the role of government are designed to reduce the provision of social welfare, meeting basic social needs, unemployment relief, etc. This legitimizes social and economic inequality of capitalism under the guise of development. ${ }^{26}$

The role of the State is evident if one considers that despite the concern of international organizations for solutions focused on market strategy; still rely on the State for the formation of appropriate institutions and the creation of a system of governance. This governance refers to the pluralism of actors, the multiplicity of institutional, to formal and informal means of interaction between the public and private sectors,

${ }^{25}$ See Schmidt, V. A., Values and discourse in the politics of adjustment, in WELFARE AND WORK IN THE OPEN ECONOMY. VOL. 1: FROM VULNERABILITY TO COMPETITIVENESS (Scharpf, F.W. \& Schmidt, V.A. eds., 2000); Pierson, P., Post-Industrial Pressure on the Mature Welfare States, in The New Politics Of THE Welfare State (Pierson, P. 2001). ${ }^{26}$ See Thomas C., Restructuring the World economy and its political implications for the Third World, in INSTABILITY AND CHANGE IN THE WORLD ECONOMY (MacEwan, A. \& Tabb, W.K. eds., 1989). 
complex interdependent relationships between levels of government and the mobilization of organizational networks that exist around public policy. ${ }^{27}$ It denotes a conceptual and theoretical representation of the coordination of social systems and the role of the State in this process. ${ }^{28}$

Thus, the State's role is complementary to the market, where new economic agents and political actors are entrepreneurs and managers of private sector organizations. The State's role is complementary to the market and accompanying where the new stars of economic development are entrepreneurs. Regional conditions for the promotion of business activities have implications in promoting integration and diversification of the regional economic structure and interagency coordination of plans, programs and projects of regional impact. ${ }^{29}$

This reassessment of the role of the State is closely associated with a reassessment of the strategies and mechanisms to promote development and achieve economic recovery in terms of Salazar Xirinachs. ${ }^{30}$

\section{THE FunCtions OF THE STATE}

Politics as activity irruption of the established order, in the concept of Rancière, involves modes of subjectivity identifiers capable of producing multitudes of functions and collective identities in the established order to be recognized in the public sphere ${ }^{31}$ By its nature, State functions are regulatory, oversight and penalties, which are met through the issuance of laws, rules, etc. State inefficiencies are manifested in poor regulation and control systems. Compliance with the regulatory functions of State requires control attributes for the enforcement of regulations and standards.

The welfare State has features that go beyond market failures, relationships and intergenerational support. The Welfare State plays

${ }^{27}$ See Rhodes, M., The Welfare State: Internal Challenges, External Constraint, in

DEVELOPMENTS IN WESTERN EUROPEAN POlitics (Rhodes, M. \& Vincent, A. eds., 1997).

${ }^{28}$ See Pierre, J., Legitimacy, Institutional Change, and the Politics of Public Administration in Sweden, 14 InTERnATIONAL POlitical SCIENCE REVIEW 4 (1993).

${ }^{29}$ See Tarapuez Chamorro, E., Una política municipal para el desarrollo de la Micro, Pequeña y Mediana Empresa, 6 RevisTa VenEZOLANA DE GERENCIA 15 (2001).

${ }^{30}$ Salazar Xirinachs, J.M., El papel del Estado y del mercado en el desarrollo económico, in EL DESARROLlO DESDE DENTRO: Un ENFOQUe NEOESTRUCTURALISTA PARA AMÉRICA LATINA (Sunkel, O. ed., 1991).

${ }^{31}$ RANCIÈRE, J., El DESACUERDO: POlíticA Y FILOSOFÍA (1996). 
several roles; including those found is the redistribution of income earners of the lower economic strata level. This is done between individuals and between generations. Thus generations cooperate so that anyone gets no harm and all of them will improve all.

Institutional and governmental structures have an influence on the development of the welfare State; arise in parallel but are interrelated in their main functions. Inward of the nation State, there are present mechanisms of political power exercise to achieve the assurance of access to wellness resources through conquest of social power. Therefore, the concern is for the institutional design that involves the political control and distribution of power in its institutional structures. ${ }^{32}$

Important functions of the welfare State are the same as for any social welfare network, to provide security and protection in case of failure of investments, occupations and risky activities. The effects of having a higher risk have implications as a production factor, and therefore is one of the most important functions that can have the welfare State. One of the most important is the social security; others are related to the insurance against uncertainty and risk. Interest and government structure determine the functions of the welfare State. When functioning properly, it brings out the best in human nature. From an economic perspective is primarily a social security institution that plays an important role in the redistribution of income.

In the logic of capitalist exploitation model, the welfare State acts as capital accumulation through the exploitation of cheap labor and theft of natural resources from other countries. Empirical evidence of a correlation between the accumulation of capital, authoritarianism and inequality are weak. It is whether to continue pursuing the welfare State as a matter of political choice and not simply to accept a forced inevitability by the blind forces of global competition. ${ }^{33}$

The Welfare State that ensures revenue induces risk taking; therefore, in advanced capitalist society it fulfills the functions that ensure continuity, stability and efficient functioning of the capitalist economic system and further integration and maintenance of an inclusive social order of groups and social classes. Recent demographic changes and future trends make important functions of the welfare State to solve big

32 See Moe, T. M., The Politics of Bureaucratic Structure, in, CAN THE GOVERNMENT Govern? (Chubb, J.E. \& Peterson, P. eds., 1989); NørGAARD, A. S., THE POlitics OF InSTITUTIONAL CONTROL (1997); Christiansen, P. M., \& Togeby, L. Institutionel magt, in PA $^{\circ}$ SPORET AF MAGTEN 11 (Christiansen, P.M. \& Togeby, L. eds., 2003).

33 See Koslowski, K. \& Follesdal, A. Restructuring the Welfare StAte (eds., 1997).

1 JOURNAL OF INSTITUTIONAL STUDIES 1 (2015) 
problems of humanity. For example the increase in the population over 65 years with the declining working age pose serious problems for sustainability and financial viability.

The adoption of these welfare programs and the exercise of regulatory and supervisory functions of the State, combined with a market economy with regulated functions to avoid excessive speculative gains, helped to accelerate sustainable economic development. These forms of social organization of production were modified to obtaining political resources of the working class in the capitalist State for welfare programs outside the sphere of the market but within the functions of State provision. The capitalist State has a dual and contradictory character because all social spending is simultaneously directed towards the functions of accumulation and legitimation. ${ }^{34}$

Under the public choice approach, the functions of the welfare State are explained by normative irregularities, such as bureaucrats seeking income benefits and seeking to expand its budget and power, as well as groups seeking income from operation of the political system decisions that are of general interest. ${ }^{35}$

Economic, political and social changes caused by globalization processes transform the nature of the political community and the nationState functions leading to a new system of government and government action. The integration of regional blocs with supranational institutions in a competitive global market environment can be regarded as the last strategic stronghold of the welfare State that resists globalization processes as the case of the Southern Cone in Latin America. This trend of economic and social policy and regional transformation reconfigures State functions and capabilities of government that responds to the collapse of governance provided by the already decadent Bretton Woods institutions.

Ideologically, the reform of the State is defined as reducing the size and functions of the State, to achieve greater efficiency and effectiveness. Thatcher and Reagan implemented this radical and extremist strategy of the liberal economy and the State functions. Reagan repudiated welfare programs and rejected the legacy of the New Deal under the concept of social provision from the cradle to the grave. ${ }^{36}$ Neoliberalism as hegemonic model of capitalism on a global scale was taken and driven by Thatcher in Britain and Reagan in the United States with the support of

34 See O'CONNOR, J. O., THE FisCAL CRISIS Of THE StATE (1973), pp. 7.

35 See Mueller, D. C. Public CHOICE II (1989).

36 See Hobsbawm, E. The Age Of Extremes: The Short Twentieth Century, 1914-1991 (1994), pp. 249. 
international financial institutions, the International Monetary Fund, the World Bank and the World Trade Organization, those promoting policies of economic and financial liberalization, deregulation, privatization, opening economies to the world market, casualization of labor relations and retraction of the presence of the State in the economy.

Unions are organizations of workers who come in defense of the institutions of the welfare State and its functions in the administration of pension funds and disease. However, labor organizations and labor unions are in crisis because they no longer represent the interests of its members. Existing unions do not necessarily represent the interests of its members, but rather they have become an instrument of labor control.

The bureaucratic, administrative and political apparatus of the public sector increases its functions and activities in all economic and social sectors. The neoliberal reform of State involves reducing the State's ability to meet social demands, which are transferred to local governments. The reform of the administrative bureaucratic State apparatus is oriented in the new managerialism, democratization processes and to consumers in competitive markets who make rational choices, which eventually reduces the citizen into a consumer. The new managerialism incorporates tools and business sector management practices that separate the political functions and the administrative functions, the exclusive activities of the State and other agents, introduces the methodology of process reengineering, systems performance tied to incentives and forms of accountability.

State reform aims to shift the responsibility of the State with respect to the company to meet the requirements of development. The development model was based on the strategy of creating growth poles promoted by regional agencies. The change in the patrimonial public administration to bureaucratic supported the formation of liberal authoritarian State in the nineteenth century, but the rise of liberal welfare State adopts new public management, so they are associated, as in the case of schemes ultra-liberal but not necessarily in the social democrats.

In fact, the changes in the powers and functions of the nation State have led to a reformulation of powers and functions that are also presented in other levels of government, especially local and municipal. Local governments are responsible for promoting development that performs as limited by the scarcity of resources and lack of capacity to intervene in domestic factors.

For the neoliberal model, the role of government centered on redistributive policies represents an unproductive expenditure and 
discourages investment competitiveness. Neoliberal rejects statist as a deformation of the functions of the State, which assumes the functions of society and individuals. Then the problem reduces to set boundaries in performing these functions. From economic rationality derives administrative rationality that seeks optimization, efficiency and effectiveness of the public goods provision in public sector organizations through the use of techniques, methods and management tools that apply in private organizations for profit is derived.

Under the neoliberal model of State, contingent public functions take into consideration those activities that can be outsourced (outsourcing) or privatized and deconstructs the main functions of the modern State to which Dror referred to as the functions of order superior of the State. ${ }^{37}$ To these public functions quota must be added decentralization.

The strategy of neoliberal modernization has been absolute under an orthodox dogma that does not distinguish differences in development between national States. In this new world economic order, development strategies are more focused on the modernization of the State through decentralization of functions. The decentralization of the functions of the national State is a trend related to changes in the accumulation mode, the scientific and technological revolution, the restructuring of the State and autonomous spaces claims raised by civil society.$^{38}$ Decentralization aims to increase the power, autonomy of decision and control of resources, responsibilities and powers of local authorities, to the detriment of the power of central government bodies. ${ }^{39}$

The approaches of political and administrative decentralization are the neoliberal in favor market-oriented to reducing State functions resulting in the elimination of neoliberal social policy, and the social that strengthens the essential functions of the State to ensure the implementation of social policy.

The implementation is done through so-called administrative reforms aimed at modernizing structures of the bureaucratic apparatus, the latest of which has been called the managerial revolution that tries to redefine the bureaucratic system without achieving the expected benefits. The

\footnotetext{
37 Dror, Y. Fortalecimiento de la capacidad de los gobiernos en materia de formulación de políticas, 7-8 GESTIÓN Y ANÁLISIS DE POLÍTICAS PÚBLICAS 18 (1996), pp. 222, available at $<$ http://revistasonline.inap.es/index.php?journal=GAPP\&page=article\&op=view\&path $\% 5 \mathrm{~B} \% 5 \mathrm{D}=106>$.

38 See Marsiglia, J. \& Pintos, G., La construcción del desarrollo local/regional: Temas, actores y nuevas modalidades de intervención, 78-79 CUADERNOS DEL CLAEH 325 (2001).

39 See Mattos, C., La descentralización ¿Una nueva panacea para impulsar el desarrollo local?, 3 REVISTA DE ECONOMÍA Y SOCIEDAD 165 (1990), pp. 165-167.
} 
economic growth strategy is oriented towards decentralization of State functions, participation and democratization. It is therefore a problem of governance rather than public administration that requires redefining the roles of the State and civil society. In this sense, The Washington Consensus oriented agenda and challenges of the institutions of civil society to replace important functions of the State, to liberalize the economy, privatizing companies and limit government intervention in the market.

Also precisely because there are no social institutions capable of strengthening a sense of civic virtue, welfare reform is seen as a way to use the State to bring what society has lost. Governing involves coordinating, influence, guidance and balance in the interaction processes between public stakeholders, politicians and interest groups and individuals. The demand capacity of some stakeholders about the State limits the alleged universalism of the public good, to adopt strategies based on focused trends, contingents, decentralized and tertiary of private sector and civil society. However, this strategic arrangement of the State is poor to achieve the public good and to satisfy the needs and social demands. In promoting equity, for example, the State accepts and institutionalizes the differences. Equity is the missing link between growth and poverty reduction.

The public sector reforms were guided by the new public management and have been enclosed by structural adjustment measures, reduction of functions and personnel, privatization and anti-corruption measures. Many of the traditional functions of the welfare State are transferred through processes of privatization of the public sector to the private sector and through processes of citizenship to civil society. State reform aims to shift the responsibility of the State to society to meet the requirements of development. This transfer of functions from the State to civil society takes place after the State has woefully neglected infrastructure and public services.

The public sector reforms are aimed at revitalizing the legitimacy of the State of universal welfare. The reform of the Latin American State incorporates the principles proposed by the neoliberal model such as thinning of the public sector, division of tasks, use of contracts, downsizing of State guidance to consumers and users, reduced intervention in the economy, control and cost recovery, increasing the capacity of government and governance, accountability, etc.

State reform is a political process that modifies the relations of power through institutional changes that can be functional, materials and domination, and the interests of the different political actors and 
economic agents, i.e. interactions modify the society, the State and the market to adapt to the demands of economic development model and the processes of economic globalization. Political changes are aimed at improving the quality of institutions through processes of economic and political flexibility to absorb environmental uncertainty.

Economic globalization imposes areas of regional integration and supranational institutions have an obvious impact on the formation of new nations and State functions from the advancement of decolonization and separation, a clear erosion of national security systems that affect feelings of national, regional or local identity. The term "Cocacolonization" that was coined in the forties and was widely used in the fifties, refers to the shock wave of American values around the globe. The processes of economic integration have affected all functions of the welfare State, but most pension systems.

Despite the difficulties which oppose the hegemonic capitalist system to the formal organization of global society, the result is the exclusion and marginalization from development processes of important social strata placed in situations of dependence of capitalist economic centers, what intended to be regarded as disposable residual population. Governments contain the functions of the welfare State to its minimum welfare expression and the minimum requirements of cohesion around the common good in the public sphere by providing social services and security, public education, care to retirees, limited regulation of economic activities, etc.

The vital impulse and creativity are in the balances. As a differentiation strategy of the functions of the State, NGOs are voluntary partnership agencies whose functions are oriented to the management and delivery of public services to the communities they serve. The voluntary association is to transfer individual actions to shared actions, so that transit of private dimension to the public and communally expressed..$^{40}$

It's convenient to talk about transformation of the functions of the nation State that its imminent removal as a result of advancing globalization processes. Education, health and other public services are dismantled and transferred to the private sector. Blyth shows that social policy has helped to build internationally competitive globalization forces that reduce and privatize the functions of the welfare State. ${ }^{41}$ The strategy to limit or reduce State functions is focused on diverting the

40 See Funes Rivas, M.J., Las organizaciones voluntarias en el proceso de construcción de la sociedad civil, Sistema: 117 REVISTA DE CIENCIAS SOCIALES 55 (1993).

${ }^{41}$ BLYTH, M. GREAT TRANSFORMATIONS (2002). 
action of social movements toward integration to non-governmental organizations, in order to control them from the same structure of State power.

\section{Discussion: THE QUESTION}

The State remains an important actor of globalization and the global political economy, whose functions are relevant to the promotion and control of the hegemonic structure of imperial capitalist system. Globalization must create economic spaces to achieve development goals according to national interests. The strategic role of the State is to adopt policies that maximize the benefits and minimize the costs of regional integration through regional strategic partnerships and agreements. Contrary to the rhetoric of entrepreneurs and transnational capitalist class, the State will continue to play an important role requiring strengthening its regulatory functions, aimed at eliminating the risks that may threaten their investments and ensure reproduction and increase of its capitals.

The transnational capitalism builds a system of institutions that overlap structures of the nation State, exceed its functions, facilitate networking supranational integration between groups belonging to the same stratum, reconfigure global social forces in dominant groups and dominated groups deepening global divide between those who benefit from the processes of globalization and those without. The integration of regional blocs with supranational institutions in a competitive global market environment can be regarded as the last strategic stronghold of the welfare State that resists globalization processes as the case of the Southern Cone in Latin America. The analysis of the welfare State should be changed in a linear fashion to a more interactive approach to its causes and defining its roles in society.

The proposed self-regulation by the capitalist system in the form of deregulation that reduces to the minimum State functions from the idea that the government should only do what is necessary was just a fantasy. The State's role in implementing the legal system led to a regulation that prevented the spontaneous development of economic and social systems.

During the last ten years a given level of consensus was reached regarding the delimitation of the complementary roles of State and market. The re nationalization or neo nationalization of State functions is a process that aims to regain some of the lost or diminished functions by the State under the application of neoliberal policies and is now one of 
the cornerstones of the expansion of large transnational corporations as the result of military and political expansion of imperial States.

The State's role is to provide regulatory frameworks to overcome market failures and the same model of minimal State. The State requires revaluing appropriate regulatory function of its activities, defining methods and effective ways to do government. State functions should complement markets by coordinating the exchange interactions and mobilize the agents of economic development of society.

An association that coordinates the interests between the community and the private and public sectors in the three levels of government, exceeds the dichotomy that considers the Owner State as opposed to market interests identified with the private sector. Failures such as information asymmetries theoretically justify and explain the functions of the welfare State beyond a safety net, not just in terms of the objectives of redistribution but perform activities where private markets are inefficient for technical reasons or would not perform.

Efforts to change the direction of government activities in a move to alter the centrality of its economic function, in order to be parallel with activist State functions in the processes of economic concentration and prioritization of social and economic relations. While the Keynesian welfare State model attempted to reduce the gaps in economic inequality, inequity and injustice within some national States, despite the monstrous populist deviations and real socialism, yet still persist and the subjugation of the new Neoliberal State model promoter of profits that benefit the owners of the large financial capital.

The model of neoliberal development strategy that favors capitalists stimulates the formation and functioning of civil society motivated by democratic values in conflict with the authoritarian State decisions, reduces its functions to give more scope to the free market. However, despite the neoliberal offensive strategy against the model of the welfare State, financial crises not only persist but are deepened and the answer is the same, prescribe more ultra-liberal measures.

Financial crises provoked maintain the functions of the welfare State levels of underdevelopment by their inability to meet the demands of a more humane and balanced society. The dismantling of the welfare State is to pay debts to creditors. Petras argues that the increasing frequency and intensity of crises have transformed the role of government from police to firefighter putting out the fire of financial conflagrations. ${ }^{42}$

42 Petras, J., "Centralidad del Estado en el mundo actual “, La Página de Petras, mayo 26, 2001, available at <http://www.rebelión.org/petrascentralidad.htm $>$. 
However, the limitation of the functions of the State's political economy does not guarantee the proper functioning of other institutions. The State is one of the social actors who can promote a more equitable and just development. A more visionary perspective is that can balance the roles of markets, States and civil society, so as to avoid excesses and regulatory structures for transparent and standardized information systems and accounting redesign. To meet local differences, an important function of the State with a focus on federalism, the State must formulate and implement differential policies that consider incentive schemes to behaviors of social and political actors to disable the existing perverse relationship between the political class and clientelism and operate as articulators of the local social economic development.

The State crisis is the result of the economic crisis, i.e. essentially a fiscal crisis. The crisis of the capitalist system is not resolved with the dismantling of the welfare State model and its social policies. The Welfare State serves to recover the losses that have private capital for depression and stagnation of economic growth due to economic crises from robbery to public goods and resources. Therefore, reactions to economic crises condemn confidence in the "free market" and seek the welfare State actions to mitigate their consequences.

The permanent crisis of social and democratic State of law and its functions more featured helps to accelerate the process of social decomposition, cultural uprooting, and fall in anomie and crime, which serves to justify the repression and criminalization mechanism. The crisis deepens in national health systems and social security but underlying is the lack of political will to provide the State the functions assigned to protect social security. State institutions undergo severe political crisis so that cause malfunctions and end in failures which the State cannot guarantee the political order.

The welfare State is not going so far as to take the democratic control of the economy so a new design of a regulator Welfare State with functions, activities and rules oriented to serve the welfare of society rather than serve the interests required by foreign capital and transnational capitalist class. The State's role is in developing programs to combat poverty and the development of a network of institutions and relationships that provide such programs. It is required the formation of horizontal networks of coordination and cooperation between municipalities in both general and sectorial programs.

The problem is that the empirical evidence of the regulatory activity of the State or the State system is different from a standpoint of a range of spheres of government, which is generated by multiple regulatory 
requirements and in the aggregate, discourages investment. This is a variance with the preferences of political leaders considered as the government and reformers within government such as the Institute for Competitiveness and external reformers such as the OECD

To evaluate an economic institution must be a model of prophecies that can serve as the basis for significant welfare judgments. It is therefore a problem of governance rather than public administration that requires redefining the roles of the State and civil society.

With the ideological crisis of neoliberalism that has implications to the economic and social crisis that undermines political systems, free market principles are questioned, the actions of civil society are promoted and the complementary roles of the State are claimed. The struggle against neoliberalism is also against the commodification of the world. The reformist left are trying to widen the functions of the State and increase public spending to preserve entitlement of social programs in a time when the capitalist system in tune with the profile of the Welfare State. A high economic growth needed to sustain public expenditure of the welfare State requires a sustainable and steady economic and financial policy.

\section{REFERENCES}

Alber, J. A framework for the comparative study of social services, 5 JOURNAL OF EUROPEAN SOCIAL POLICY 2 (1995).

Alber, J. Continuity and change, 16 POLITICS AND SOCIETY 4 (1995).

Blais, A., Blake, D. and Dion, S. Do Parties Make a Difference? Parties and the Size of Government in Liberal Democracies, 37 AMERICAN JOURNAL OF POLITICAL SCIENCE 40 (1993).

BLYTH, M. GREAT TRANSFORMATIONS (2002).

Christiansen, P. M., \& Togeby, L. Institutionel magt, in $\mathrm{PA}^{\circ}$ SPORET AF MAGTEN 11 (Christiansen, P.M. \& Togeby, L. eds., 2003). 
Dror, Y. Fortalecimiento de la 292ociedade292 de los gobiernos uma 292ocieda de formulación de políticas, 7-8 GESTIÓN Y ANÁLISIS DE POLÍTICAS PÚBLICAS 18 (1996), available at $<\underline{\text { http://revistasonline.inap.es/index.php?journal=GAPP\&page }=\text { article\&o }}$ $\mathrm{p}=$ view\&path $\% 5 \mathrm{~B} \% 5 \mathrm{D}=106>$.

Dunning, J. H. Governments and the macro-organization of economic activity: an Historical and spatial perspective, 4 REVIEW OF INTERNATIONAL POLITICAL ECONOMY 1 (1997).

ESPING-ANDERSEN, G. POlitics AgAinst MARKETS: THE SOCIAL DEMOCRATIC ROAD TO POWER (1985).

Estefanía, J. "La enfermedad moral del capitalismo", Granito de arena, Agosto 7 del 2002, Argentina (2002).

Fleury, S. Reforma del Estado uma América Latina. Hacia 292ocie?, 160 NuEVA SOCIEDAD 58 (1999).

Funes Rivas, M.J., Las organizaciones voluntarias uma el 292ociedad de construcción de la 292ociedade civil, Sistema: 117 REVISTA DE CIENCIAS SOCIALES 55 (1993).

Hicks, A. \& Misra, J., Political Resources and the Growth of Welfare in Affluent Capitalist Democracies, 1960-1982, 99 AMERICAN JOURNAL OF SOCIOLOGY 3 (1993).

Hobsbawm, E. The Age of Extremes: THe SHORt Twentieth Century, 1914-1991 (1994).

Iversen, T. The Dynamics of Welfare State Expansion: Trade Openness, Deindustrialization, and Partisan Politics, in THE New POLITICs OF THE Welfare State (Pierson, P. ed., 2001). 
Iversen, T. \& Cusack, T. R. The Causes of Welfare State Expansion: Deindustrialization or Globalization?, 52 WORLD POLITICS 3 (2000).

Koslowski, K. \& Follesdal, A. Restructuring the Welfare State (eds., 1997).

LumSDaine, D. H. MORAL Vision IN INTERNATIONAL Politics: THE FOREIGN AID REGIME 1949-1989 (1993).

Marsiglia, J. \& Pintos, G., La construcción del desarrollo local/regional: Temas, actores y nuevas modalidades de intervención, 78-79 CUADERNOS DEL CLAEH 325 (2001).

Mattos, C., La descentralización ¿Uma nueva panacea para impulsar el desarrollo local?, 3 REVISTA DE ECONOMÍA Y SOCIEDAD 165 (1990).

Moe, T. M., The Politics of Bureaucratic Structure, in, CAN THE GOVERNMENT GOVERn? (Chubb, J.E. \& Peterson, P. eds., 1989).

Moudud, J. K. \& Zacharias, A., The social wage, welfare policy, and the phases of capital accumulation (The Jerome Levy Economics Institute Working Paper No. 291, 1999).

MuelLer, D. C. Public ChOICE II (1989).

Myles, J. \& Quadagno, J., Political Theories of the Welfare State, 76 Social SERVICE REVIEW 1 (2002).

NørGaARD, A. S., The Politics Of Institutional Control (1997).

O'Brien, M. \& PenNa, S., Theorising Welfare EnLIGHTENMENT AND MODERN SOCIETY (1998). 
O'CONNOR, J. O., THE FisCAL CRISIS OF THE STATE (1973).

Peón Solís, A., A propósito de la globalización: ¿es inminente la desaparición del Estado?, 102 Este País: TENDENCIAS Y OPINIONES 33 (1999).

Petras, J., "Centralidad del Estado uma el mundo actual “, La Página de Petras, mayo 26, 2001, available at $<$ http://www.rebelión.org/petrascentralidad.htm $>$.

Pierre, J., Legitimacy, Institutional Change, and the Politics of Public Administration in Sweden, 14 INTERNATIONAL POLITICAL SCIENCE ReVIEW 4 (1993).

Pierson, P., Post-Industrial Pressure on the Mature Welfare States, in THE New Politics of the Welfare State (Pierson, P. 2001).

Pierson, P. Coping with Permanent Austerity: Welfare State Restructuring in Affluent Democracies, in The New Politics of the Welfare State (Pierson, P. 2001).

Pierson, P. \& Smith, M. Bourgeois revolutions? The policy consequences of resurgent conservatism, 25 COMPARATIVE POLITICAL STUDIES 4 (1993).

Pontusson, J., Explaining the Decline of European Social Democracy: The Role of Structural Economic Change, 47 WORLD POLITICS 4 (1995).

Quadagno, J.B., The TRAnsformation of Old Age Security: Class and Politics IN THE AMERICAN Welfare StATE (1988).

RANCIÈRE, J., El DESACUERDO: POLÍTICA Y FILOSOfÍA (1996). 
Rhodes, M., The Welfare State: Internal Challenges, External Constraint, in DEVELOPMENTS IN WESTERn EuROPEAN POlitics (Rhodes, M. \& Vincent, A. eds., 1997).

Sassen, S., The State and the global city: Notes towards a conception of placecentered governance, 1 COMPETITION \& CHANGE 31 (1995).

Salazar Xirinachs, J.M., El papel del Estado y del mercado uma el desarrollo económico, in El DeSARROLLO DESDE DENTRO: UMA ENFOQUE NeOESTRUCTURALISTA PARA AMÉRICA LATINA (Sunkel, O. ed., 1991).

Schmidt, V. A., Values and discourse in the politics of adjustment, in WELFARE AND WORK IN THE OPEN ECONOMY. VOL. 1: FROM VULNERABILITY TO COMPETITIVENESS (Scharpf, F.W. \& Schmidt, V.A. eds., 2000).

Skocpol, T., Bringing the State Back in: Strategies of Analysis in Current Research, in BRINGING THE STATE BACK IN (Evans, P.B., Rueschemeyer, D. \& Skocpol, T. eds., 1985).

Svallfors, S., Worlds of Welfare and Attitudes to Redistribution: A Comparison of Eight Western Nations, 13 EuROPEAN SOCIOLOGICAL REVIEW 3 (1997).

Tarapuez Chamorro, E., Uma política municipal para el desarrollo de la Micro, Pequeña y Mediana Empresa, 6 Revista Venezolana De Gerencia 15 (2001).

Thomas C., Restructuring the World economy and its political implications for the Third World, in INSTABILITY AND CHANGE IN THE WORLD ECONOMY (MacEwan, A. \& Tabb, W.K. eds., 1989).

Torres-Rivas, E., La 295ociedade civil uma la construcción democrática: notas desde uma perspectiva crítica, 8/9 REVISTA INSTITUCIONES Y DESARROLLO 143 (2001), available at 
$<$ www.iigov.org/iigov/pnud/bibliote/revista/revista8 9/docs/revis8 04.h $\underline{t \mathrm{~m}}>$.

WiLENSKY, H., THE Welfare STATE AND EQUALITY (1975).

WiLENSKY, H., THE Welfare STATE AND EQUALITY: STRUCTURAL AND

IDEOLOGICAL RoOTS OF PUbLIC EXPENDITURES (1975). 